DOI: 10.32844/2222-5374-2020-104-2.14

УДК: 342.922 (477)

Гезь П.. .,

аспірант кафедри адміністративного права, процесу та адміністративної діяльності

Дніпропетровського державного університету внутрішніх справ

\title{
УДОСКОНАЛЕННЯ НОРМАТИВНО-ПРАВОВОЇ ОСНОВИ ПРОТИДІЇ ПРАВОПОРУШЕННЯМ У СФЕРІ ДЕРЖАВНОЇ РЕЄСТРАЦІЇ В УКРАЇНІ: ПОШУК ПЕРСПЕКТИВ
}

Актуальність статті полягає в тому, що державна реєстрація як інститут головним чином спрямована на громадян. Це зумовлено тим, що відповідно до статті 3 Конституції України, утвердження і забезпечення прав і свобод людини $\epsilon$ головним обов'язком держави. Втім, належне забезпечення прав і свобод людини потребує не лише ефективної діяльності відповідних державних органів. Для процедур державної реєстрації не менш важливою є сучасна нормативна основа, завдяки якій створюється основа для удосконалення практичної складової такої діяльності. Про актуальність теми дослідження свідчать численні матеріали у засобах масової інформації про порушення прав фізичних та юридичних осіб, внаслідок недоліків процедур реєстрації. У статті здійснено аналіз сучасного стану нормативно-правової основи протидії правопорушенням у сфері державної реєстрації в Україні та визначено перспективи ії удосконалення. Звернуто увагу на повноту та ефективність правового регулювання процедури державної реєстрації прав на нерухоме майно. Визначено позищії щодо удосконалення державної реєстрації юридичних осіб, фізичних осіб підприємців та громадських формувань, що не мають статусу юридичної особи. Розглянуто як наукові позищії, так і законодавчі новації у цій сфері. Наголошено на пріоритеті превентивних заходів та комплексному характері законодавчих ініціатив. Підтримано ідею про концептуальний підхід у оптимізації процедур державної реєстрації. Зроблено висновок про урахування моментів, що мають знайти законодавче закріплення, зокрема: 1) технічне запровадження двофакторної біометричної ідентифікації особи;

2) оформлення всіх рішень уповноваженого органу правління юридичної особи на нотаріальних бланках з використанням QR-кодів; 3) використання на всіх документах, що подаються для проведення державної реєстрації спеціальних QR-кодів; 4) розробка єдиної електронної бази даних для обміну документами між нотаріусами, судами та органами державної влади; 5) обрання головою та секретарем загальних зборів юридичної особи лише тих осіб, які є їі засновниками (учасниками); 6) використання на судових рішеннях QR-кодів для отримання інформації без шифрування особистих даних.

Ключові слова: державна реєстрація, перспективи, нерухоме майно, нормативно-правова основа, пропозиції, законодавство. 
Актуальність. Державна реєстрація як інститут головним чином спрямована на громадян. Це зумовлено тим, що відповідно до статті 3 Конституції України, утвердження і забезпечення прав і свобод людини $\epsilon$ головним обов'язком держави [1]. Втім, належнезабезпечення прав і свобод людини потребує не лише ефективної діяльності відповідних державних органів. Для процедур державної реєстрації не менш важливою є сучасна нормативна основа, завдяки якій створюється основа для удосконалення практичної складової такої діяльності. Про актуальність теми дослідження свідчать численні матеріали у засобах масової інформації про порушення прав фізичних та юридичних осіб, внаслідок недоліків процедур реєстрації.

Як зазначає, Т. Борисенко, спрощення процедур реєстраційних процедур, спрямоване на поліпшення позицій України в рейтингу Doing Business, фактично полегшило життя різного роду мисливцям за чужою нерухомістю та бізнесом [2]. Водночас, вести мову про те, що сфера державної реєстрації $\epsilon$ належним чином унормованою в Україні - зарано. У пошуку перспектив протидії правопорушенням у сфері державної реєстрації бракує цілісності погляду на проблему, що знижує позитивний ефект окремих новацій та залишає приводи для дискусії.

Стан наукової розробки теми. Наукові дослідження, присвячені удосконаленню процедурдержавноїреєстрації доволі широко представлені у вітчизняній правовій науці. Можна відмітити науковий доробок таких фахівців, як: С. Іванова, А. Кеча, О. Коровайко, Л. Котяш, О. Красногора, О. Луніна, Н. Майка, В. Нікітіна, С. Слободянюк, Я. Тамаря А. Шинкарук та багато інших. Втім, незважаючи на велику кількість наукових публікацій, проблеми удосконалення нормативно-правової основи лишаються актуальними. Причина цього полягає у триваючій інтеграції до Європейського Союзу (ЄC), що вимагає оптимізації реєстраційних процедур та їх приведення у відповідність до європейських стандартів.

Мета статті полягає у здійсненні наукового аналізу перспектив удосконалення нормативно-правової основи протидії правопорушенням у сфері державної реєстрації в Україні.

Виклад основного матеріалу. Переходячи до аналізу перспектив удосконалення протидії правопорушенням у сфері державної реєстрації на нормативно-правовому рівні, слід зазначити що умовно їх можна поділити на ті, що пропонуються експертами у науково-публіцистичних матеріалах та ті, що подаються у вигляді законопроектів до Верховної Ради України. Так, досліджуючи правовий режим даних державного реєстру нерухомого майна, О. Коровайко наголошує на тому, що зміни у національному законодавстві стосуються в основному розв'язання конкретних проблем і не мають системного характеру. На сьогодні не розроблено відповідної концепції розвитку адміністративного законодавства, у якій було б визначено основні положення, спрямовані на удосконалення адміністративно-правових норм, що, у свою чергу, забезпечило б створення правового інституту державної реєстрації речових прав на нерухоме майно [3, с. 182].

Так, у червні 2020 набрала чинності Постанова Кабінету Міністрів України від 13.05.2020 № 399 «Про внесення змін до деяких постанов Кабінету Міністрів України у сфері державної реєстрації», якою було внесено 
зміни до Порядку державної реєстрації речових прав на нерухоме майно та їх обтяжень, затвердженого постановою Кабінету Міністрів України від 25.12.2015 року № 1127. До відповідних новацій віднесено: а) заява власника об'єкта нерухомого майна про заборону вчинення реєстраційних дій щодо власного майна не підлягає реєстраціїу випадках, коли державним реєстратором не встановлено особу заявника або не встановлено належність об'єкта нерухомого майна на право власності; б) державний реєстратор повинен повідомити власника, користувача, обтяжувача про заяви інших осіб, подані відносно нерухомості, права на яку зареєстровано за ними; в) можливість внесення відомостей до Державного реєстру нерухомості про проведену реконструкцію; г) для державної реєстрації права власності на об'єкт незавершеного будівництва, у тому числі, що підлягає приватизації, замість технічного паспорта подається документ, що містить опис об'єкта незавершеного будівництва за результатами технічної інвентаризації такого об’єкта [4]. Вбачається, що вказані заходи мають сприяти посиленню антирейдерської діяльності та дозволять встановити додаткові гарантії для захисту права власності, що безумовно заслуговує на підтримку.

Що стосується державної реєстрації юридичних осіб, фізичних осіб - підприємців і громадських формувань та їх приведення у відповідність до положень Закону № 340-IX та постанови Кабінету Міністрів України від 19.08.2020 № 721, 16 вересня 2020 року. Так, Законом № 340-IX внесено зміни до Закону України «Про державну реєстрацію юридичних осіб, фізичних осіб - підприємців та громадських формувань» у частині можливості внесення до Єдиного державного реєстру юридичних осіб, фізичних осіб - підприємців та громадських формувань відомостей про встановлення вимоги учасника юридичної особи щодо нотаріального засвідчення справжності його підпису під час прийняття рішень з питань діяльності відповідної юридичної особи та/або вимоги нотаріального посвідчення правочину, предметом якого $є$ частка такого учасника у статутному (складеному) капіталі (пайовому фонді) відповідної юридичної особи, чи скасування такої вимоги. У свою чергу, Постановою Кабінету Міністрів України від 19.08.2020 № 721 зменшено строки розгляду документів за проведення державної реєстрації змін до відомостей про структурне утворення політичної партії як юридичної особи у скорочені строки [5].

Подібно до наведеного, наказом Міністерства юстиції України від 01.04.2020 № 1307/5 «Про внесення змін до Порядку державної реєстрації юридичних осіб, фізичних осіб - підприємців та громадських формувань, що не мають статусу юридичної особи» [6], оптимізовано проведення державної реєстрації за заявами в електронній формі.

У травні 2019 року у Верховній Раді України був зареєстрований законопроект від 15.05.2019 № 10293 про внесення змін до Кодексу України про адміністративні правопорушення щодо посилення відповідальності державних реєстраторів за порушення у сфері державної реєстрації під час проведення державної реєстрації юридичної особи, фізичної особи-підприємця або громадського формування та державної реєстрації речових прав на нерухоме майно та їх обтяжень [7]. Не применшуючи значення вказаного документа, зауважимо, що просте посилення 
адміністративної відповідальності навряд чи виступатиме ефективним інструментом протидії правопорушенням у сфері державної реєстрації. Тут мають вживатися більш комплексні дії, насамперед превентивного, а не карального характеру.

В цьому аспекті О. Оніщук відмічає, що наразі на законодавчому рівні діють норми, які передбачають обов'язкове використання спеціальних бланків нотаріальних документів, що зводить до мінімуму можливість підробки документів. Окрім того, запроваджено багатофакторну автентифікація для державних реєстраторів якзахист від несанкціонованих проникнень до реєстрів, а також нові штрафи за порушення порядку проведення державної реєстрації. При цьому встановлено оновлені критерії, за якими визначатиметься ступінь відповідальності державного реєстратора за допущене порушення у сфері державної реєстрації, що повинно поставити остаточну крапку в роботі «чорних реєстраторів». Найголовніше, що комунальні підприємства та їхні філії позбавлені права здійснювати реєстраційні дії [8]. Підтримуючи його думку, необхідно відмітити, що перераховані заходи все ж $є$ недостатньо дієвими, адже інформація про так звані «рейдерські атаки» часто зустрічається у засобах масової інформації

У свою чергу, Н. Борисенко вбачає необхідними наступні дії: а) підвищення кваліфікаційних вимог, що пред’являються до державних реєстраторів; скасування «чорного ринку» реєстраційних послуг і «кришування» цього ринку; підвищення заробітної плати державних реєстраторів; реформування органів в системі державної реєстрації; наявність політичної волі на ефективне розслідування злочинів, пов'язаних з незаконними захопленнями підприємств [2].

Коментуючи викладену вище позицію, слід зауважити, що тестування для державних реєстраторів прав на нерухоме майно та/або державних реєстраторів юридичних осіб, фізичних осіб - підприємців та громадських, яке організовує та проводить Міністерство юстиції України з 2019 року, не відповідає наявним потребам, створює надмірні бар'єри для доступу до професії Реєстратора та, відповідно, погіршує доступ до адміністративних послуг для населення. У багатьох випадках, особи, призначені на посади державних реєстраторів, не можуть отримати доступ до реєстрів Мін'юсту та не приступають до виконання повноважень, оскільки не можуть скласти відповідні тести. Натомість, експертами напряму з покращення якості надання адміністративних послуг для населення Програми «U-LEAD 3 Європою», пропонується удосконалити організацію тестування та зробити завдання тестів більш наближеними до виконання повноважень державних реєстраторів, опублікувати повний перелік тем та питань для належної, в тому числі самостійної, підготовки до тестів. Основною метою тестування має бути не встановлення перешкод та обмеження доступу до цієї професії, а підвищення професійної компетентності претендентів саме на етапі підготовки до нього. Альтернативним варіантом вирішення проблеми може бути запровадження навчальних курсів для осіб, які мають намір здійснювати функції державних реєстраторів, збільшення кількості заходів з підвищення кваліфікації посадовими особами, які вже такі функції виконують [9]. 
Щодо майбутніх перспектив удосконалення державної реєстрації, вона вбачається у оновленні програмного забезпечення державних реєстрів та запровадження е-нотаріату: створенні Єдиного реєстру нотаріальних дій, електронного нотаріального архіву та електронного нотаріального документообігу, що сприятиме зручності доступу громадян до нотаріальних і реєстраційних послуг [10]. Звичайно така пропозиція $\epsilon$ доцільною для впровадження, але виникає питання із забезпечення належної інформаційної безпеки даних відповідного реєстру від несанкціонованого втручання у його роботу та доступу до відповідних баз даних.

Характеризуючи нормативно-правові акти, що регулюють адміністративні процедури 3 державної реєстрації речових прав на нерухоме майно, Я. Тамаря зазначає, що основними проблемами правового регулювання зазначеної сфери лишається відсутність концепції здійснення адміністративної процедури з державної реєстрації речових прав на нерухоме майно та невідповідність підзаконних нормативноправових актів законам [11, с.166]. Погоджуючись із тезою про внутрішню неузгодженість нормативно-правової основи у сфері державної реєстрації, ми не вбачаємо доцільним розробку концепції для реалізації лише одного з багатьох видів реєстраційних процедур. Концептуальною тут має бути саме нові ідеологія та зміст державної реєстрації, як правового інституту, який поступово має наближатися за стандартами простоти і прозорості до законодавства держав-учасниць ЄС.

Насамкінець, звернімо увагу на заяву Нотаріальної палати України про підтримку законодавчих ініціатив щодо запровадження виключно судового порядку оскарження рішень, дій або бездіяльності державних реєстраторів у сфері державної реєстрації прав на нерухомість та бізнесу [12]. Дійсно, така пропозиція виглядає слушною, але з іншого боку це матиме наслідком переобтяження адміністративних судів, що є доволі спірним.

Висновки. На підставі викладеного та керуючись власною позицією щодо перспектив удосконалення нормативно-правової основи протидії правопорушенням у сфері державної реєстрації, пропонуємо зупинитись на наступних моментах, що мають знайти нормативне закріплення:

1) технічне запровадження двофакторної біометричної ідентифікації особи при вчиненні будь-яких дій, пов'язаних з державною реєстрацію;

2) оформлення на нотаріальних бланках з використанням QR-кодів всіх рішень уповноваженого органу правління юридичної особи;

3) використання на всіх документах, що подаються для проведення державної реєстрації спеціальних QR-кодів, що надасть можливість перевірити такі документи на автентичність;

4) розробка єдиної електронної бази даних для обміну документами між нотаріусами, судами та органами державної влади, що мінімізуватиме можливість підробки документів;

5) передбачити можливість обрання головою та секретарем загальних зборів юридичної особи лише тих осіб, які $є$ її засновниками (учасниками);

6) використання на судових рішеннях QR-кодів надасть можливість державному реєстратору перевірити наявність рішення в Єдиному дер- 
жавному реєстрі судових рішень інформацію без шифрування особистих даних.

\section{СПИСОК ВИКОРИСТАНИХ ДЖЕРЕЛ}

1. Конституція України: Закон України від 28.06.1996 № 254к/96-ВР. Відомості Верховної Ради України від 23.07.1996. 1996. № 30, Ст. 141.

2. Борисенко Т. Порушення порядку реєстрації бізнесу та нерухомості: чому посилення відповідальності не $\epsilon$ панацеєю URL: https://jurliga. ligazakon.net/ua/analitycs /186554_porushennya-poryadku-restrats-bznesuta-nerukhomost-chomu-posilennya-vdpovdalnost-ne--panatseyu

3. Коровайко О.С. Правовий режим даних державного реєстру нерухомого майна: дисертація к.ю.н. 12.00.07. Київ. 2019. 222 с.

4. Удосконалено порядок державної реєстрації речових прав на нерухоме майно та їх обтяжень. Коментар управління з питань реєстрації виконкому Криворізької міської ради URL: https://krmisto.gov.ua/ua/news/ detail/id/4632.html

5. Увага! Мін'юст вніс зміни до форм реєстраційних документів URL: https://news.dtkt.ua/accounting/automation/65006

6. Про внесення змін до Порядку державної реєстрації юридичних осіб, фізичних осіб - підприємців та громадських формувань, що не мають статусу юридичної особи: наказ Міністерства юстиції України від 01.04.2020 № 1307/5 Офіційний вісник України від 03.04.2020. № 26, стор. 308, ст. 988.

7. Про внесення змін до Кодексу України про адміністративні правопорушеннящодопосилення відповідальностідержавнихреєстраторів за порушення у сфері державної реєстрації під час проведення державної реєстрації юридичної особи, фізичної особи-підприємця або громадського формування та державної реєстрації речових прав на нерухоме майно та їх обтяжень: проект Закону від 15.05.2019 № 10293. URL: http://w1.c1.rada. gov.ua/pls/zweb2/webproc4_1?pf3511=65936

8. Оніщук О. Удосконалено розгляд скарг у сфері держреєстрації URL: https://www.kmu.gov.ua/news/olga-onishchuk-udoskonaleno-rozglyad-skargu-sferi-derzhreyestraciyi

9. Пропозиції Програми «U-LEAD з Європою» щодо державної політики у сфері адміністративних послуг. URL: https://tsnap.ulead.org.ua/ wp-content/uploads/2019/12/Zvedeni-polisi-zapysky-Final.pdf

10. Оніщук О. Захист від рейдерства: оптимізація державних механізмів. Юридична газета online. 2020. № 2 (708) URL: https://yur-gazeta. com/publications/practice/zemelne-agrarne-pravo/zahist-vid-reyderstvaoptimizaciya-derzhavnih-mehanizmiv.html

11. Тамаря Я.В. Адміністративні процедури з державної реєстрації речових прав на нерухоме майно: дис. к.ю.н. 12.00.07. Запоріжжя. 2018. 206 c.

12. Нотаріальна палата України підтримує запровадження виключно судового порядку оскарження рішень, дій або бездіяльності державних реєстраторів. 5.11.2020. URL: https://npu.ua/news/sud-poryadok-proekt/ 


\section{P. HeZ}

\section{IMPROVING THE LEGAL BASIS FOR COUNTERACTION OFFENSES IN THE STATE REGISTRATION SPHERE IN UKRAINE: SEARCHING FOR PROSPECTS}

The relevance of the article is that state registration as an institution is mainly aimed at citizens. This is due to the fact that according to Article 3 of the Constitution of Ukraine, the establishment and protection of human rights and freedoms is the main duty of the state. However, the proper provision of human rights and freedoms requires not only the effective operation of relevant state bodies. No less important for state registration procedures is the modern regulatory framework, which creates a basis for improving the practical component of such activities. The relevance of the research topic is evidenced by numerous materials in the media about violations of the rights of individuals and legal entities due to shortcomings in the registration procedures. The article analyzes the current state of the legal framework for counteraction offenses in the sphere of state registration in Ukraine and identifies prospects for its improvement. Attention is paid to the completeness and efficiency of legal regulation of the state registration procedure of rights to immovable property (real estate). Positions on improvement of the state registration of legal entities, physical persons - businessmen and public formations which do not have the status of the legal entity are defined. Both scientific positions and legislative innovations in this field are considered. Emphasis is placed on the priority of preventive measures and the comprehensive nature of legislative initiatives. The idea of a conceptual approach in optimizing state registration procedures is supported. The conclusion on the account of the moments which should find legislative fixing, in particular: 1) technical introduction of two-factor biometric identification of the person;2) execution of all decisions of the authorized body of the legal entity on notarized forms with the use of QR-codes; 3) use of special QR-codes on all documents submitted for state registration; 4) development of a single electronic database for the exchange of documents between notaries, courts and public authorities; 5) election of the legal entity as chairman and secretary of the general meeting only of those persons who are its founders (participants); 6) use of QR-codes on court decisions to obtain information without encryption of personal data.

Keywords: state registration, prospects, real estate, regulatory framework, proposals, legislation. 